\section{Replacing Conventional Nursery Crop Nutrient Inputs with Vermicompost for Container Production of Hibiscus moscheutos L. 'Luna Blush'}

\author{
Michelle S. McGinnis ${ }^{1,4}$, Stuart L. Warren ${ }^{2}$, and Ted E. Bilderback ${ }^{3}$ \\ Department of Horticultural Science, 2721 Founders Drive, North Carolina \\ State University, Raleigh, NC 27695-7609
}

Additional index words. herbaceous perennial, nutrient use efficiency, water use ratio, worm castings

\begin{abstract}
Vermicomposting of pig manure is a waste management approach that has been shown to be economically and technologically feasible and yields a value-added end product, vermicompost (VC), that contains plant-available nutrients. The objective of this study was to determine if conventional nursery crop inputs could be replaced by commercially available VC (derived from pig manure) for production of Hibiscus moscheutos 'Luna Blush' L. (hibiscus). Hibiscus was grown in 3.8-L containers containing pine bark amended with $11 \%$ sand (by vol.), $1.8 \mathrm{~kg} \cdot \mathrm{m}^{-3}$ dolomitic limestone, and $0.9 \mathrm{~kg} \cdot \mathrm{m}^{-3}$ micronutrient package (PBS) or pine bark amended with $20 \% \mathrm{VC}$ (by vol.) (20VC). Plants were topdressed with one of three controlled-release fertilizers (CRF) containing only nitrogen $(\mathrm{N})$; $N$ and potassium $(\mathrm{K})$; or $\mathrm{N}$, phosphorus $(\mathrm{P})$, and $\mathrm{K}$. The four treatments included PBS with 17-6-12 (PBS + NPK), 20VC with 17-6-12 $(20 \mathrm{VC}+\mathrm{NPK}), 20 \mathrm{VC}$ with $17-0-12(20 \mathrm{VC}+\mathrm{NK})$, and 20VC with 17-0-0 $(20 \mathrm{VC}+\mathrm{N})$. The PBS + NPK treatment, which was supplied with conventional nursery crop nutrient inputs (limestone, sulfated micronutrients, and CRF containing NPK), served as the control treatment to represent the industry standard. All treatments were irrigated to maintain a leaching fraction ( $\mathrm{LF}=$ volume leached $\div$ volume applied) of 0.24 . Daily inorganic nitrogen (IN-N) and dissolved reactive phosphorus (DRP) effluent contents were determined. Plants were harvested at 35 and $56 \mathrm{~d}$ after potting (DAP). Total plant nutrient contents of $\mathrm{P}$, calcium (Ca), magnesium (Mg), and sulfur (S), iron (Fe), manganese, zinc $(\mathrm{Zn})$, copper $(\mathrm{Cu})$, and boron $(\mathrm{B})$ were equivalent or greater for all three 20VC treatments compared with PBS + NPK. However, total plant $K$ content of $20 \mathrm{VC}+\mathrm{N}$ was less than $20 \mathrm{VC}+\mathrm{NPK}, 20 \mathrm{VC}+\mathrm{NK}$, and PBS + NPK. Regardless of lower $\mathrm{K}$ content in the 20VC $+\mathrm{N}$ treatment, all three 20VC treatments had equivalent total plant dry weight and number of flowers. Furthermore, all three 20VC treatments averaged $\mathbf{5 8 \%}$ and $\mathbf{4 0} \%$ greater plant dry weight than PBS + NPK at 35 and 56 DAP, respectively, and $93 \%$ more flowers than PBS + NPK at 56 DAP. All three 20VC treatments had similar IN-N and DRP effluent contents. However, the three $20 \mathrm{VC}$ treatments averaged 4.3 $\times$ more IN-N effluent content and 59 $\times$ DRP effluent content than PBS + NPK. The nutrient use efficiencies for all treatments were similar, in which nitrogen use efficiency ranged from $9 \%$ to $15 \%$ and phosphorus use efficiency ranged from $7 \%$ to $12 \%$. In conclusion, this source of $\mathrm{VC}$ provided equivalent or greater $\mathrm{P}, \mathrm{Ca}, \mathrm{Mg}, \mathrm{S}, \mathrm{Fe}, \mathrm{Zn}$, and $\mathrm{Cu}$ but less $K$ for plant uptake compared with the industry standard (control) treatment and produced larger plants with more flowers than the control. This suggests that dolomitic lime, sulfated micronutrients, and $P$ can be eliminated as substrate additives.
\end{abstract}

Vermicomposting is an economically and technologically feasible organic waste management approach that yields the value-added product vermicompost (VC) or worm castings (Albanell et al., 1988; Atiyeh et al., 2000; Edwards, 1995; Hartenstein and Hartenstein, 1981). During the process, earthworms and microorganisms stabilize organic waste in an aerobic, moist, nonthermophillic environment (Sylvia et al., 2005). The resulting product has been successfully marketed as a pine bark amendment to progressive nursery crop producers (Bob Binkley, CEO, NatureWorks Organics, Advance, NC, personal communication). Benefits to growers include greater plant growth and flower production (Arancon et al., 2008; Hidalgo and Harkess, 42-d-old petunia (Petunia $\times$ hybrida Vilm.) had greater dry shoot weight and flower number when grown in $20 \% \mathrm{VC}$ [derived from cattle manure (Bos sp.)] compared with a control $(0 \% \mathrm{VC})$ [complete liquid fertilizer $\left(200 \mathrm{mg} \cdot \mathrm{L}^{-1} \mathrm{~N}\right)$ applied to all treatments] (Arancon et al., 2008). Additionally, 42-d-old tomato (Lycopersicon esculentum Mill. 'Rutgers) and marigold (Tagetes patula L. 'Queen Sophia') transplants had greater dry shoot weights when grown in $20 \%$ VC [derived from pig manure (Sus sp.)] compared with a control $(0 \% \mathrm{VC})$ [complete liquid fertilizer $\left(200 \mathrm{mg} \cdot \mathrm{L}^{-1} \mathrm{~N}\right)$ applied to all treatments starting $14 \mathrm{~d}$ after germination] (Bachman and Metzger, 2008). Atiyeh et al. (2002) and Bachman and Davis (2000) have reported similar findings with 121-d-old marigold 'Queen Sophia' and 112-d-old Magnolia virginiana L. liners, respectively, when grown in $\mathrm{VC}$ (derived from pig manure) amended substrates. Because sufficient fertilizer nutrients were provided, SprengelLeibig's law of the minimum (Epstein and Bloom, 2005) suggests that additional nutrients provided by VC were not solely responsible for increased plant growth. The exact mechanism that causes increased plant growth associated with $\mathrm{VC}$ is unclear. Nevertheless, several researchers have suggested it may be the result of synergistic effects of a variety of factors, including improved substrate physical properties, greater availability of plant nutrients, influence of hormone-like or humic substances, and the presence of beneficial microorganisms (Arancon et al., 2004; Tomati and Galli, 1995).

Regardless of the degree in which nutrients supplied by VC increase crop growth (or not), plant-available nutrients provided by VC should be able to benefit containerized crop production systems by reducing or eliminating fertilizer nutrient inputs from conventional fertilizer sources. Evidence that plant-available nutrients are associated with VC was shown with increasing extractable nutrient concentrations of substrates amended with increasing rates of VC (Bachman and Metzger, 2007; Hidalgo et al., 2006). These results demonstrate plantavailable nutrients are associated with $\mathrm{VC}$ but do not quantify or estimate plant-available nutrient content. Evidence that plant-available nutrients are provided by VC was also demonstrated with increased growth of plants produced in unfertilized VC (derived from pig and cattle manure) amended substrates compared with plants produced in an unfertilized control (0\% VC) (Atiyeh et al., 2001; Bachman and Metzger, 2008; Hidalgo et al., 2006). However, VC will not supply sufficient quantities of all plant essential nutrients, because plants grown in unfertilized VC (derived from pig and cattle manure) amended substrates produced very little biomass (Hidalgo et al., 2006) and/or less biomass compared with plants grown in a fertilized control ( $0 \% \mathrm{VC})$ (Atiyeh et al., 2001; Bachman and Metzger, 2008). The specific growth-limiting nutrient(s) were not investigated by these studies. 
Plant-available nutrient content $(\mathrm{N}$ in particular) and rate of nutrient release can be predicted from mineralization study results, because $\mathrm{N}$ from compost (including vermicompost) is continually released through mineralization processes (Baldwin and Greenfield, 2006). However, because mineralization experiments are lengthy and labor-intensive, nutrient availability coefficients, the fraction of the total nutrient concentration estimated to be plant-available, are often used as guidelines to predict the available nutrient content from a composted material (Baldwin and Greenfield, 2006).

Identification of growth-limiting nutrients supplied by various sources of VC was conducted by Handreck (1986). Handreck (1986) evaluated eight sources of VC amended at $30 \%$ to pine bark for their ability to supply plant-available nutrients. Sufficient phosphorus $(\mathrm{P})$, calcium $(\mathrm{Ca})$, magnesium $(\mathrm{Mg})$, iron $(\mathrm{Fe})$, manganese $(\mathrm{Mn})$, zinc $(\mathrm{Zn})$, copper $(\mathrm{Cu})$, boron $(\mathrm{B})$, and molybdenum was supplied by all sources for production of 59-d-old Matthiola incana L. (stock) with the exception of one VC source in which high levels of $\mathrm{Zn}$ resulted in poor plant growth. The ability of VC to provide sufficient potassium $(\mathrm{K})$ and sulfur $(\mathrm{S})$ depended on the waste material from which the VC was derived, and sufficient $\mathrm{N}$ was not provided by any of the eight VC sources (Handreck, 1986). Results of a laboratory mineralization study of vermicomposted pig manure (McGinnis, 2010) supported Handreck's results that N supplied by VC is growth-limiting. McGinnis (2010) estimated a $20 \% \mathrm{VC}$ (by vol.) amended pine bark substrate provided $\approx 300 \mathrm{mg}$ per 3.8 -L container plant-available $\mathrm{N}$ over 8 weeks. This is less than $10 \% \mathrm{~N}$ that would be commonly applied (3-5 g N/3.8-L container) as a controlled-release fertilizer (CRF). Based on these results, VC will not provide sufficient $\mathrm{N}$ necessary to maximize growth of

Received for publication 2 Dec. 2008. Accepted for publication 6 May 2009.

This research was funded in part by the North Carolina Agricultural Research Service (NCARS), Raleigh, NC, and the Environmental Protection Agency (EPA) Science to Achieve Results (STAR) Fellowship.

Use of trade names in this publication does not imply endorsement by the NCARS or EPA of products named nor criticism of similar ones not mentioned. Appreciation is extended to William M. Reece and Mary Lorscheider for technical assistance and Cavelle Brownie for statistical assistance.

From a thesis submitted by M.S.M. in partial fulfillment of the requirements for the Ph.D. degree. ${ }^{1}$ Former Graduate Assistant. Currently: Agronomist, NC Department of Agricultural \& Consumer Services, Agronomic Services Division, Plant/ Waste/Solution Analysis Section, 1040 Mail Service Center, Raleigh, NC 27699.

${ }^{2}$ Currently: Professor and Head, Kansas State University, Department of Horticulture, Forestry, and Recreation Resources, Manhattan, KS 66503.

${ }^{3}$ Professor, Interim Director of JC Raulston Arboretum.

${ }^{4}$ To whom reprint requests should be addressed; e-mail michelle.mcginnis@ncagr.gov. containerized crops. Therefore, a supplemental $\mathrm{N}$ source is necessary to maximize production of container growth crops produced in a VC amended substrate.

We hypothesized that pine bark amended with $\mathrm{VC}$ derived from pig manure can provide all nutrients to maximize nursery crop growth with the exception of $\mathrm{N}$ and possibly $\mathrm{K}$ and $\mathrm{S}$. The objectives of this study were to determine which conventional nursery crop nutrient inputs (dolomitic limestone, sulfated micronutrients, and CRF with NPK) could be substituted with VC for production of Hibiscus moscheutos L. 'Luna Blush' (hibiscus).

\section{Materials and Methods}

Substrate chemical properties. Samples of $\mathrm{VC}$ and pine bark were collected and submitted to the NC Department of Agriculture and Consumer Services (NCDA\&CS), Agronomic Division, Raleigh for total nutrient analysis, cation exchange capacity, electrical conductivity (EC), and $\mathrm{pH}$ (Table 1). Before analysis, samples were dried at $65^{\circ} \mathrm{C}$ and ground with a stainless steel grinder (ED5 Wiley Mill; Thomas Scientific, Swedesboro, NJ) through a 1-mm screen (Campbell and Plank, 1992). Total carbon and $\mathrm{N}$ concentrations were determined by oxygen combustion gas chromatography with an elemental analyzer (NA 1500; CE Elantech Instruments, Lakewood, NJ) (Campbell, 1992). Total P, K, $\mathrm{Ca}, \mathrm{Mg}, \mathrm{S}, \mathrm{Fe}, \mathrm{Mn}, \mathrm{Zn}, \mathrm{Cu}, \mathrm{B}$, and sodium (Na) concentrations were determined with an inductively coupled plasma (ICP) spectrometer (Donohue and Aho, 1992) (Optima 3300 DV ICP Emission Spectrometer; Perkin Elmer Corporation, Shelton, CT) after open-vessel $\mathrm{HNO}_{3}$ digestion in a microwave digestion system (CEM Corp., Matthews, NC) (Campbell and Plank, 1992). EC was determined using a 1:2 (v/v) substrate to distilled water extract, and $\mathrm{pH}$ was determined using a $1: 1(\mathrm{v} / \mathrm{v})$ substrate to distilled water slurry. Cation exchange capacity was determined by summation of basic cations (excluding $\mathrm{Na}$ ) and buffer acidity (Mehlich et al., 1976).

Experimental design and substrates. The study was a randomized complete block design with four treatments, four blocks, and seven plants (experimental units) per plot. Substrates included milled pine bark (less than $1.25 \mathrm{~cm}$, aged 1 year) amended with $20 \%$ VC (by vol.) (NatureWorks Organics, Advance, NC) derived from pig manure (hereafter referred to as 20VC) and pine bark amended with $11 \%$ sand (by vol.), $1.8 \mathrm{~kg} \cdot \mathrm{m}^{-3}$ dolomitic limestone, and $0.9 \mathrm{~kg} \cdot \mathrm{m}^{-3}$ Micro$\max ^{\circledR}$ (Scotts, Marysville, OH) (hereafter referred to as PBS). Substrates were blended with a $0.76-\mathrm{m}^{-3}$ rotary mixer (Bouldin \& Lawson, LLC, McMinnville, TN). The 20VC substrate had an equivalent VC loading rate a $270 \mathrm{mg} \mathrm{VC} / 3.8-\mathrm{L}$ container (dry mass basis).

Fertilizers and nutrients. The CRFs formulated by Harrell's Fertilizer Inc. (Lakeland, FL) were $17 \mathrm{~N}-2.4 \mathrm{P}-10 \mathrm{~K}(17-6-12,3-$
4 month, $12.3 \%$ urea, $3.4 \%$ nitrate, $1.3 \%$ ammonia), $17 \mathrm{~N}-0 \mathrm{P}-10 \mathrm{~K} \quad(17-0-10, \quad 3-4$ month, $13.6 \%$ urea and $3.4 \%$ nitrate), and $17 \mathrm{~N}-0 \mathrm{P}-0 \mathrm{~K}(17-0-0,3-4$ month, $17 \%$ urea). Fertilizers were applied as a topdressing at a rate of $5 \mathrm{~g} \mathrm{~N} / 3.8 \mathrm{~L}(29.4 \mathrm{~g}$ fertilizer per container). To ensure $\mathrm{N}$ was not limiting, the rate of applied $\mathrm{N}$ was higher than the CRF incorporation rate of 0.75 to $0.9 \mathrm{~kg} \mathrm{~N} / \mathrm{m}^{3}$ (2.8-3.4 mg N/3.5-L container) recommended by Pilon (2006). For one plant per plot, CRF was divided into two half-ellipseshaped bags $(15.9 \mathrm{~cm} \times 5.8 \mathrm{~cm})$ made from mosquito mesh (No-See-Um Mosquito Net; REI, Sumner, WA; Catalog Number 601044) and placed on the substrate surface (to simulate topdressing) for quantification of nutrients remaining in the CRF at the study termination.

The cumulative available $\mathrm{N}\left[\mathrm{N}(20 \%)_{\text {rel }}\right]$ provided by $20 \% \mathrm{VC}$ substrates after 8 weeks was estimated at $305 \mathrm{mg} \mathrm{N} / 3.8-\mathrm{L}$ container as determined by the following first-order nutrient release model developed from a laboratory mineralization study using vermicomposted pig manure McGinnis (2010): $\mathrm{N}(20 \%)_{\text {rel }}=\mathrm{a}\left(1-\mathrm{e}^{-\mathrm{kt}}\right)$, where $\mathrm{a}=9.8 \%$ (the potentially available $\mathrm{N}$ percentage of the total $\mathrm{N}$ loading rate), $\mathrm{k}=0.13$ week $^{-1}$ (the firstorder rate constant), and $t=8$ weeks. The initial total $\mathrm{N}$ loading rate from the $\mathrm{VC}$ was $4868 \mathrm{mg} / 3.8 \mathrm{~L}$. Based on the nutrient release model, the total estimated available $\mathrm{N}$ was $477 \mathrm{mg} \mathrm{N}$, and the estimated available $\mathrm{N}$ released at Week 8 was $305 \mathrm{mg} \mathrm{N}$.

The available $\mathrm{P}$ provided by $20 \% \mathrm{VC}$ substrates was estimated at $1721 \mathrm{mg} \mathrm{P}$ per 3.8-L container based on the NCDA\&CS Plant/Waste/Solution Analysis Section P availability coefficient of 0.75 for composted swine waste (Brenda R. Cleveland, Chief, Plant/ Waste/Solution Analysis Section, Agronomic Division, NCDA\&CS, Raleigh, personal communication). The initial total $\mathrm{P}$ loading rate from the VC was $4590 \mathrm{mg} / 3.8 \mathrm{~L}$. Assuming $\mathrm{P}$ will be available in one growing season (16 weeks), the plant-available P at Week 16 was calculated to be $3442 \mathrm{mg} / 3.8 \mathrm{~L}$. McGinnis

Table 1. Initial nutrient concentrations of substrate components.

\begin{tabular}{lcc}
\hline Measure & Vermicompost $^{\mathrm{z}}$ & Pine bark $^{\mathrm{z}}$ \\
\hline Nitrogen $\left(\mathrm{mg} \cdot \mathrm{g}^{-1}\right)$ & $18 \pm 2$ & $4.1 \pm 0.04$ \\
Phosphorus $\left(\mathrm{mg} \cdot \mathrm{g}^{-1}\right)$ & $17 \pm 2$ & $0.4 \pm 0.07$ \\
Potassium $\left(\mathrm{mg} \cdot \mathrm{g}^{-1}\right)$ & $1.5 \pm 0.2$ & $0.9 \pm 0.15$ \\
Calcium $\left(\mathrm{mg} \cdot \mathrm{g}^{-1}\right)$ & $55 \pm 7$ & $4.6 \pm 0.01$ \\
Magnesium $\left(\mathrm{mg} \cdot \mathrm{g}^{-1}\right)$ & $2.3 \pm 0.3$ & $0.7 \pm 0.01$ \\
Sulfur $\left(\mathrm{mg} \cdot \mathrm{g}^{-1}\right)$ & $3.5 \pm 0.5$ & $0.4 \pm 0.03$ \\
Iron $\left(\mu \mathrm{g} \cdot \mathrm{g}^{-1}\right)$ & $4,333 \pm 565$ & $3,002 \pm 162$ \\
Manganese $\left(\mu \mathrm{g} \cdot \mathrm{g}^{-1}\right)$ & $480 \pm 45$ & $143 \pm 4$ \\
Zinc $\left(\mu \mathrm{g} \cdot \mathrm{g}^{-1}\right)$ & $550 \pm 64$ & $39 \pm 2$ \\
Copper $\left(\mu \mathrm{g} \cdot \mathrm{g}^{-1}\right)$ & $112 \pm 11$ & $12 \pm 4$ \\
Boron $\left(\mu \mathrm{g} \cdot \mathrm{g}^{-1}\right)$ & $0.2 \pm 0.2$ & $2 \pm 0$ \\
Sodium $\left(\mu \mathrm{g} \cdot \mathrm{g}^{-1}\right)$ & $571 \pm 70$ & $286 \pm 30$ \\
Carbon:nitrogen & $8.4 \pm 0.01$ & $120 \pm 3$ \\
$\mathrm{pH}$ & $5.6 \pm 0.0$ & $4.1 \pm 0.0$ \\
EC $^{\mathrm{y}}\left(\mathrm{dS} \cdot \mathrm{m}^{-1}\right)$ & $5.5 \pm 0.3$ & $0.4 \pm 0.06$ \\
$\mathrm{CEC}^{\mathrm{x}}\left(\mathrm{meq} / 100 \mathrm{~cm}^{3}\right)$ & $61.1 \pm 3.1$ & -
\end{tabular}

${ }^{\mathrm{z}}$ Means \pm 1 SE based on three observations.

${ }^{\mathrm{y}} \mathrm{EC}=$ electrical conductivity.

${ }^{\mathrm{x}} \mathrm{CEC}=$ cation exchange capacity. 
(2010) and Nair et al. (2003) reported a zeroorder (linear) nutrient release model of $\mathrm{P}$ from compost; therefore, the plant-available $\mathrm{P}$ estimated to be released at Week 8 was $1721 \mathrm{mg} \mathrm{P}, 50 \%$ of that estimated to be released at Week 16. It should be noted that "There is no universally accepted method to determine plant available phosphorus in compost" (Thompson, 2003).

Treatments, plant material, and irrigation. The four treatments yielded from the substrates and fertilizer combinations were: $20 \mathrm{VC}+\mathrm{NPK}(20 \% \mathrm{VC}$ and 17-6-12), $20 \mathrm{VC}+\mathrm{NK}(20 \% \mathrm{VC}$ and $17-0-10), 20 \mathrm{VC}$ $+\mathrm{N}(20 \% \mathrm{VC}$ and $17-0-0)$, and PBS + NPK (PBS and 17-6-12). Treatment PBS + NPK served as an industry standard (or control) receiving conventional nursery crop nutrient inputs. Conventional nutrients include dolomitic limestone (to provide liming adjustment, $\mathrm{Ca}$, and $\mathrm{Mg}$ ), sulfated micronutrients (to provide $\mathrm{S}, \mathrm{Fe}, \mathrm{Mn}, \mathrm{Zn}, \mathrm{Cu}$, and $\mathrm{B}$ ), and CRF containing NPK as recommended by the best management practices guide for producing nursery crops (Yeager et al., 2007).

On 22 May 2006, seed-propagated Hibiscus moscheutos L.'Luna Blush' (hibiscus) transplants obtained from Ball Seed Co. (Chicago, IL) were potted into 3.8-L black containers, placed on 16 separate plots at the Horticulture Field Laboratory at NC State Univ., Raleigh, and topdressed with CRF. Each gravel-covered plot $(8 \times 1 \mathrm{~m})$ was underlain with corrugated plastic at a $2 \%$ slope, which directed all leachate from each plot to a 19-L collection vessel. Hibiscus is a hardy perennial (USDA hardiness zone 4-9) native to the southeastern United States. The compact, branched, shrubby growth habit lends itself to production in 3.8-L containers. The 6-inch to 8-inch flowers, which open in the morning and senesce each evening, start to show color as early as 7 weeks after transplant (Pilon, 2006). When flowering, hibiscus offers excellent color impact at the point of sale.

Irrigation was applied through pressurecompensated spray stakes (Acu-Spray Stick; Wade Mfg. Co., Fresno, CA; $200 \mathrm{~mL} \cdot \mathrm{min}^{-1}$ ) with the daily total volume divided into three cycles (1200, 1500, and $1600 \mathrm{HR})$. Volumes of irrigation water applied (influent) and leached (effluent) for each plot were measured daily (volumetrically), and leaching fraction (LF) was calculated according to the following equation: $\mathrm{LF}=$ volume leached $\div$ volume applied. Influent volumes were measured as the volume collected in a 4-L vessel from a spray stake on each plot, and effluent volumes were determined by the volume collected in a 19-L leachate vessel at each plot. Influent volumes were adjusted daily to maintain the LF for each plot. Data were compiled to determine cumulative influent per 3.8-L container and cumulative effluent per 3.8-L container. Cumulative volume water retained per 3.8-L container was calculated as the sum of the daily difference between influent and effluent volumes per container. Water use ratio (WUR) was calculated according to the following equation:
WUR $\left(\mathrm{mL} \cdot \mathrm{g}^{-1}\right)=$ cumulative volume water retained by per $3.8-\mathrm{L}$ container at day of harvest $\div$ total plant dry mass. Effluent volumes were measured after rain events with less than $0.64 \mathrm{~cm}$ of rain; however, data collected on these days were not used in the cumulative influent and effluent calculations. Rain events with greater than $0.64 \mathrm{~cm}$ of rain resulted in overflow of the 19-L leachate vessels; thus, the exact volume was not known and analysis of the leachate would not provide useful information because content could not be calculated. A total of 31.8 $\mathrm{cm}$ of rain fell on 17 separate days during the study resulting in $8 \mathrm{~d}$ of data not included in cumulated totals.

Plant growth and nutrient content. On 23 June 2006 [35 d after potting (DAP)] and 18 July 2006 (56 DAP), one and two plants, respectively, per plot of hibiscus were harvested and partitioned into roots, stems, leaves, and flower buds. Substrate was removed from roots using a high-pressure water stream, and plants were dried at $65^{\circ} \mathrm{C}$ to a constant weight $(5 \mathrm{~d})$ before obtaining dry weights of all segregated parts. On flowering, dates and number of open flowers were recorded for each plant and removed on senescence (within $24 \mathrm{~h}$ ). Total plant dry weight was calculated according to the following equation: total dry weight $(\mathrm{g})=$ root dry weight + stem dry weight + leaf dry weight + flower bud dry weight.

All tissues were ground separately using a Foss Tecator Cyclotec ${ }^{\mathrm{TM}} 1093$ sample mill (Cyclotec; Analytical Instruments, LLC, Golden Valley, MN) to pass a $0.5-\mathrm{mm}$ sieve or smaller. Stem and roots were ground initially with a Model 4 bench, 1HP Wiley Mill (Thomas Scientific, Swedesboro, NJ) to pass through a $6.0-\mathrm{mm}$ sieve or smaller before passing through the Cyclotec. Tissue samples were analyzed for $\mathrm{N}, \mathrm{P}, \mathrm{K}, \mathrm{Ca}, \mathrm{Mg}$, $\mathrm{S}, \mathrm{Fe}, \mathrm{Mn}, \mathrm{Zn}, \mathrm{Cu}$, and $\mathrm{B}$ concentrations by the NCDA\&CS, Agronomic Division, by methods described previously. Total nutrient content was determined by multiplying dry weight by nutrient concentration.

Effluent nutrient contents, nutrient budgets, and nutrient use efficiencies (nitrogen and phosphorus). A nutrient budget was developed for each treatment to quantify the watersoluble fate of $\mathrm{N}$ and $\mathrm{P}$ added as $\mathrm{CRF}$ and VC. Recovered nutrient $(\mathrm{RN})$ for $\mathrm{N}\left(\mathrm{RN}_{\mathrm{N}}\right)$ and $\mathrm{P}\left(\mathrm{RN}_{\mathrm{P}}\right)$ was calculated as follows: $\mathrm{RN}=$ nutrient in plant + cumulative nutrient lost with effluent + water-soluble nutrient remaining in substrate + nutrient remaining in CRF. The nutrient use efficiency (NUE) for $\mathrm{N}\left(\mathrm{NUE}_{\mathrm{N}}\right)$ and $\mathrm{P}\left(\mathrm{NUE}_{\mathrm{P}}\right)$ are as follows: $\mathrm{NUE}=\{$ plant absorbed nutrient $\div[$ (added nutrient by CRF and VC) (nutrient remaining in $\mathrm{CRF}+$ water-soluble nutrient remaining in substrate) $\}$ * 100 .

Total $\mathrm{N}$ and $\mathrm{P}$ in plant tissue were determined by NCDA\&CS as described previously. Nitrogen in the effluent, substrate, and CRF were quantified as $\mathrm{N}$ partitioned as water-soluble ammonium $\left(\mathrm{NH}_{4}-\mathrm{N}\right)$ and nitrate $\left(\mathrm{NO}_{3}-\mathrm{N}\right)$ and $\mathrm{P}$ was quantified as dissolved reactive $\mathrm{P}$ (DRP). Inorganic $\mathrm{N}$ (IN-N) was calculated as the sum of $\mathrm{NH}_{4}-\mathrm{N}$ and $\mathrm{NO}_{3}-\mathrm{N}$. Water-soluble nutrients remaining in the substrate (released from VC or CRF) at 56 DAP were measured on the extract from a 1:3 (v/v) substrate to deionized water slurry that was shaken for $1 \mathrm{~h}$ and filtered through a Whatman \#2 filter (Whatman, Inc., Florham Park, NJ). Nutrients remaining in the CRF were determined by blending CRF prills remaining in the nylon mesh bags at 56 DAP with deionized water for $1 \mathrm{~min}$ and filtering through a Whatman \#2 filter. The effluent, substrate extract, and CRF solution samples were analyzed colorimetrically using a continuous Flow Injection Analyzer (QuikChem 8500 System; Lachat Instruments-A Hach Company Brand, Loveland, $\mathrm{CO})$ to quantify $\mathrm{NH}_{4}-\mathrm{N}, \mathrm{NO}_{3}-\mathrm{N}$, and DRP.

Statistical analysis. All variables were analyzed using Proc analysis of variance in SAS Version 9.01 (SAS Inst. Inc., Cary, NC). Treatment comparisons were made by Fisher protected least significant difference $(P=0.05)$.

\section{Results and Discussion}

Plant growth. At 35 and 56 DAP, stem and leaf dry weights were similar for all three $20 \mathrm{VC}$ treatments, and stem and leaf dry weights of all $20 \mathrm{VC}$ treatments were greater than PBS + NPK (Table 2). Flower bud dry weight and number were similar for all four treatments at 35 DAP. At 56 DAP, flower bud dry weight and number were similar for all three 20VC treatments, and flower bud dry weight and number of all 20VC treatments were greater than PBS + NPK. Root dry weights of hibiscus grown in $20 \mathrm{VC}+\mathrm{NPK}$ and $20 \mathrm{VC}+\mathrm{NK}$ were greater than $20 \mathrm{VC}+\mathrm{N}$ and PBS + NPK at DAP 35 and greater than $20 \mathrm{VC}+\mathrm{N}$ at 56 DAP. $20 \mathrm{VC}+\mathrm{N}$ without $\mathrm{K}$ resulted in less root growth compared with 20VC treatments with $\mathrm{K}$ applied, yet root growth was similar to PBS + NPK. The lower root growth of $20 \mathrm{VC}+\mathrm{N}$ was offset by greater leaf growth, resulting in similar total dry weights of all three $20 \mathrm{VC}$ treatments, which were all greater than PBS + NPK at 56 DAP. No nutrient deficiency visual symptoms were observed on any treatment on either harvest date. Plants grown in all treatments were flowering and judged to be saleable at 56 DAP

Increased top (shoot and stem) dry weight, root dry weight, and/or flower production of containerized crops grown in $\approx 20 \%$ VC substrates has been reported by others (Arancon et al., 2008; Atiyeh et al., 2002; Bachman and Metzger, 2008; Hidalgo and Harkess, 2002; McGinnis, 2007). However, in contrast to experimental treatments here, complete fertilizers were provided. Thus, the benefit of increased growth for plants produced in substrates amended with this source of $\mathrm{VC}$ can be realized even when all fertilizer nutrient inputs except $\mathrm{N}$ are eliminated. The reduction of conventional nutrient inputs and the use of "recycled" nutrients from the VC may be of interest to some growers. 
Table 2. Effect of nutrient inputs on dry tissue weights, flower number, and water use ratio (WUR) of Hibiscus moscheutos 'Luna Blush' at 35 and $56 \mathrm{~d}$ after potting (DAP).

\begin{tabular}{|c|c|c|c|c|c|c|c|c|}
\hline \multirow{2}{*}{$\frac{\text { DAP }}{35}$} & \multirow[b]{2}{*}{ Substrate $^{z}$} & Root dry wt & Stem dry wt & Leaf dry wt & Flower bud dry wt & Total dry weight & \multirow[b]{2}{*}{ Flower number ${ }^{y}$} & \multirow[b]{2}{*}{$\mathrm{WUR}^{\mathrm{x}}\left(\mathrm{mL} \cdot \mathrm{g}^{-1}\right)$} \\
\hline & & \multicolumn{5}{|c|}{$(\mathrm{g})$} & & \\
\hline \multirow{4}{*}{56} & $20 \mathrm{VC}+\mathrm{NK}$ & $3.8 \mathrm{a}$ & $2.5 \mathrm{a}$ & $7.1 \mathrm{a}$ & $0.10 \mathrm{a}$ & $13.6 \mathrm{a}$ & $14.0 \mathrm{a}$ & $898 \mathrm{~b}$ \\
\hline & $20 \mathrm{VC}+\mathrm{NPK}$ & $17.0 \mathrm{a}$ & $12.6 \mathrm{a}$ & $18.4 \mathrm{a}$ & $5.02 \mathrm{a}$ & $53.1 \mathrm{a}$ & $54.5 \mathrm{a}$ & $659 \mathrm{a}$ \\
\hline & $20 \mathrm{VC}+\mathrm{NK}$ & $16.3 \mathrm{ab}$ & $12.6 \mathrm{a}$ & $18.1 \mathrm{a}$ & $5.55 \mathrm{a}$ & $52.5 \mathrm{a}$ & $54.6 \mathrm{a}$ & $678 \mathrm{a}$ \\
\hline & $20 \mathrm{VC}+\mathrm{N}$ & $13.3 \mathrm{c}$ & $12.7 \mathrm{a}$ & $19.6 \mathrm{a}$ & $4.41 \mathrm{a}$ & $50.1 \mathrm{a}$ & $58.4 \mathrm{a}$ & $639 \mathrm{a}$ \\
\hline
\end{tabular}

${ }^{2} \mathrm{PBS}=8$ pine bark:1 sand with $1.8 \mathrm{~kg} \cdot \mathrm{m}^{-3}$ dolomitic limestone and $0.9 \mathrm{~kg} \cdot \mathrm{m}^{-3}$ Micromax ${ }^{\circledR}$ (Scotts, Marysville, $\left.\mathrm{OH}\right) ; 20 \mathrm{VC}=20 \%$ vermicompost-amended pine bark (by volume); $\mathrm{NPK}=17 \mathrm{~N}-2.4 \mathrm{P}-10 \mathrm{~K} ; \mathrm{NK}=17 \mathrm{~N}-0 \mathrm{P}-10 \mathrm{~K} ; \mathrm{N}=17 \mathrm{~N}-0 \mathrm{P}-0 \mathrm{~K}$.

${ }^{y}$ Flower number $=$ number of senesced flowers removed before harvest.

${ }^{x}$ WUR $($ water use ratio $)=$ volume of water retained by substrate $(\mathrm{mL}) \div$ total plant dry weight $(\mathrm{g})$.

wEach mean is based on four observations.

'Means within each variable (column) and DAP followed by the same letter are not significantly different as determined by Fisher's protected least significant difference at $P \leq 0.05$.

Irrigation measures. The LF averaged $0.24,0.23,0.25$, and 0.25 for $20 \mathrm{VC}+\mathrm{NPK}$, $20 \mathrm{VC}+\mathrm{NK}, 20 \mathrm{VC}+\mathrm{N}$, and PBS + NPK, respectively. No differences between treatments were detected at either 35 or 56 DAP for cumulative influent per 3.8-L container $($ mean $=16.2 \mathrm{~L} \pm 0.1$ for $35 \mathrm{DAP}$; mean $=$ $42.6 \mathrm{~L} \pm 1.0$ for $56 \mathrm{DAP})$, cumulative effluent per 3.8-L container (mean $=4.5 \mathrm{~L} \pm 0.2$ for 35 DAP; $9.9 \mathrm{~L} \pm 0.8$ for 56 DAP), or cumulative water retained per $3.8-\mathrm{L}$ container $($ mean $=$ $11.8 \mathrm{~L} \pm 0.5$ for $35 \mathrm{DAP} ; 32.7 \mathrm{~L} \pm 0.8$ for 56 DAP) (data not presented). At 35 DAP, WUR was similar for $20 \mathrm{VC}$ treatments, and all were improved compared with the PBS treatment. At 56 DAP, WUR was similar for all treatments (Table 2).

The greater plant growth of the 20VC treatments compared with PBS treatment at 35 DAP in conjunction with similar cumulative water retained per $3.8-\mathrm{L}$ container volumes for all treatments resulted in a statistically significant improvement of use of water resources (i.e., improved WUR) (Table 2). Although statistical WUR differences were not detected at 56 DAP, similar irrigation volumes were applied to all treatments, yet the $20 \mathrm{VC}$ treatments had greater growth occurred compared with the PBS treatment (Table 2). If production time was shortened as a result of increased growth of plants grown in 20VC substrates, it would follow to reason that less irrigation volume would be used.

Plant tissue nutrient content. Root, stem, leaf, flower bud, and total plant content of $\mathrm{P}$, $\mathrm{Ca}, \mathrm{Mg}, \mathrm{S}, \mathrm{Fe}, \mathrm{Mn}, \mathrm{Zn}, \mathrm{Cu}$, and $\mathrm{B}$ grown in the $20 \mathrm{VC}$ treatments were equivalent to or greater than PBS + NPK (Table 3). These results indicate this source of $\mathrm{VC}$ supplied these nutrients in equivalent or greater amounts than conventional fertilizer inputs. However, total plant $\mathrm{K}$ content of $20 \mathrm{VC}+\mathrm{N}$ was less than $20 \mathrm{VC}+\mathrm{NPK}, 20 \mathrm{VC}+\mathrm{NK}$, and
PBS + NPK (Table 3). This indicates 20VC did not supply plant-available $\mathrm{K}$ at quantities equivalent to that supplied by conventional fertilizer inputs. Total plant $\mathrm{N}$ content of PBS + NPK was less than $20 \mathrm{VC}+\mathrm{NPK}$ and $20 \mathrm{VC}$ $+\mathrm{N}$ and equivalent to that of $20 \mathrm{VC}+\mathrm{NK}$. Total $\mathrm{N}$ content of $20 \mathrm{VC}+\mathrm{N}$ was greater than that of $20 \mathrm{VC}+\mathrm{NPK}$ (Table 3 ). These results suggest that the additional $\mathrm{N}$ associated with the $\mathrm{VC}$ is not responsible (at least directly) for the increased plant growth associated with the 20VC treatments nor was $\mathrm{N}$ growthlimiting for the PBS + NPK treatment.

Total plant nutrient uptake was similar for all three 20VC treatments with the following exceptions: $\mathrm{K}, \mathrm{Ca}$, and $\mathrm{Mg}$. Total plant $\mathrm{K}$ content of $20 \mathrm{VC}+\mathrm{N}$ was less than $20 \mathrm{VC}+$ $\mathrm{NPK}$ and $20 \mathrm{VC}+\mathrm{NK}$; however, total plant $\mathrm{Ca}$ and $\mathrm{Mg}$ of $20 \mathrm{VC}+\mathrm{N}$ was greater than the other two 20VC treatments. Similar trends were observed with root, stem, leaf, and flower bud $\mathrm{K}$ content, stem and leaf $\mathrm{Ca}$

Table 3. Effect of nutrient inputs on macronutrient content of Hibiscus moscheutos 'Luna Blush' tissues at $56 \mathrm{~d}$ after potting.

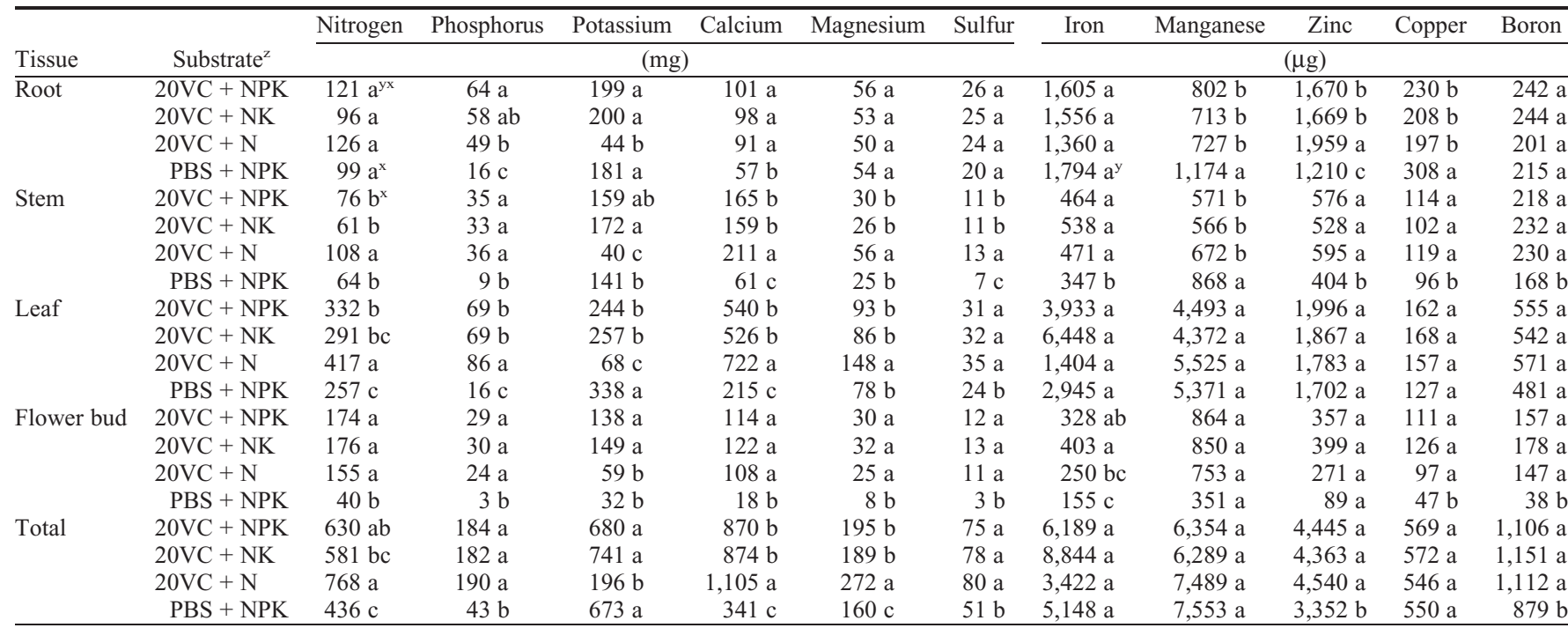

${ }^{2} \mathrm{PBS}=8$ pine bark: 1 sand with $1.8 \mathrm{~kg} \cdot \mathrm{m}^{-3}$ dolomitic limestone and $0.9 \mathrm{~kg} \cdot \mathrm{m}^{-3}$ Micromax ${ }^{\circledR}$ (Scotts, Marysville, $\mathrm{OH}$ ); $20 \mathrm{VC}=20 \%$ vermicompost-amended pine bark (by volume); $\mathrm{NPK}=17 \mathrm{~N}-2.4 \mathrm{P}-10 \mathrm{~K} ; \mathrm{NK}=17 \mathrm{~N}-0 \mathrm{P}-10 \mathrm{~K} ; \mathrm{N}=17 \mathrm{~N}-0 \mathrm{P}-0 \mathrm{~K}$.

${ }^{y}$ Each mean is based on four observations.

${ }^{x}$ Means within each variable (nutrient) and plant tissue type followed by the same letter are not significantly different as determined by Fisher's protected least significant difference at $P \leq 0.05$. 
content, and stem and leaf $\mathrm{Mg}$ content. The increased $\mathrm{Ca}$ and $\mathrm{Mg}$ total content of $20 \mathrm{VC}+$ $\mathrm{N}$ may be a result of reduced competitive uptake inhibition by $\mathrm{K}$ (Mill and Jones, 1991). Some physiological roles of K can be replaced by other cations, which may explain why no decreased plant growth was associated with $20 \mathrm{VC}+\mathrm{N}$ treatments (Wyn-Jones et al., 1979).

Effluent nutrient contents, nutrient budgets, phosphorus). At 56 DAP, the IN-N and DRP effluent content of the 20VC treatments were similar, and the IN-N and DRP effluent contents of the $20 \mathrm{VC}$ treatments were greater than PBS + NPK (Tables 4 and 5). The and nutrient use efficiencies (nitrogen and

average IN-N effluent content of the $20 \mathrm{VC}$ treatments $(243 \mathrm{mg})$ was $186 \mathrm{mg}$ greater than the effluent content of PBS + NPK (47 mg) (Table 4), and the average DRP effluent content of the 20VC treatments $(415 \mathrm{mg})$ was $408 \mathrm{mg}$ greater than the effluent content of PBS + NPK (7 mg). The 20VC treatment IN-N effluent content average of $126 \mathrm{mg}$ at 5 DAP and DRP effluent content average of $208 \mathrm{mg}$ at $10 \mathrm{DAP}$ amounted to $50 \%$ of the effluent content at 56 DAP (data not presented).

The contents of $\mathrm{N}$ recovered $\left(\mathrm{RN}_{\mathrm{N}}\right)$ for all $20 \mathrm{VC}$ treatments were similar, and $\mathrm{RN}_{\mathrm{N}}$ content of all $20 \mathrm{VC}$ treatments was greater than PBS + NPK. Interestingly, the $\mathrm{RN}_{\mathrm{N}}$

Table 4. Nitrogen partition of Hibiscus moscheutos 'Luna Blush' grown with different nutrient inputs at $56 \mathrm{~d}$ after potting.

\begin{tabular}{|c|c|c|c|c|}
\hline Nitrogen partition & $20 \mathrm{VC}+\mathrm{NPK}^{\mathrm{z}}$ & $20 \mathrm{VC}+\mathrm{NK}^{\mathrm{z}}$ & $20 \mathrm{VC}+\mathrm{N}^{\mathrm{z}}$ & $\mathrm{PBS}+\mathrm{NPK}^{\mathrm{z}}$ \\
\hline \multicolumn{5}{|l|}{ Inputs } \\
\hline Fertilizer (mg) & $5,000^{y}$ & 5,000 & 5,000 & 5,000 \\
\hline Vermicompost (mg) & $305^{y}$ & 305 & 305 & 0 \\
\hline \multicolumn{5}{|l|}{ Outputs } \\
\hline Effluent $\mathrm{NO}_{3}-\mathrm{N}(\mathrm{mg})$ & $233 \mathrm{a}^{\mathrm{yx}}$ & $227 \mathrm{a}$ & $222 \mathrm{a}$ & $48 \mathrm{~b}$ \\
\hline Effluent $\mathrm{NH}_{4}-\mathrm{N}(\mathrm{mg})$ & $15 \mathrm{a}^{\mathrm{yx}}$ & $14 \mathrm{ab}$ & $17 \mathrm{a}$ & $9 \mathrm{~b}$ \\
\hline Hibiscus (mg) & $630 \mathrm{ab}^{\mathrm{yx}}$ & $581 \mathrm{bc}$ & $768 \mathrm{a}$ & $436 \mathrm{c}$ \\
\hline \multicolumn{5}{|l|}{ Remaining in system } \\
\hline Substrate $\mathrm{NO}_{3}-\mathrm{N}(\mathrm{mg})$ & $12.6 \mathrm{ab}^{\mathrm{yx}}$ & $29.1 \mathrm{ab}$ & $6.0 \mathrm{~b}$ & $40.3 \mathrm{a}$ \\
\hline Substrate $\mathrm{NH}_{4}-\mathrm{N}$ (mg) & $11.7 \mathrm{~b}^{\mathrm{yx}}$ & $22.9 \mathrm{ab}$ & $49.3 \mathrm{a}$ & $9.6 \mathrm{~b}$ \\
\hline Fertilizer $\mathrm{NO}_{3}-\mathrm{N}(\mathrm{mg})$ & $126.0 \mathrm{~b}^{\mathrm{yx}}$ & $147.8 \mathrm{a}$ & $0.2 \mathrm{c}$ & $122.3 \mathrm{~b}$ \\
\hline Fertilizer $\mathrm{NH}_{4}-\mathrm{N}(\mathrm{mg})$ & $36.9 \mathrm{a}^{\mathrm{yx}}$ & $1.3 \mathrm{~b}$ & $1.7 \mathrm{~b}$ & $34.1 \mathrm{a}$ \\
\hline Recovered nutrient $\left(\mathrm{RN}_{\mathrm{N}}\right)^{\mathrm{w}}(\mathrm{mg})$ & $1,065 \mathrm{a}^{\mathrm{yx}}$ & $1,022 \mathrm{a}$ & $1,064 \mathrm{a}$ & $699 \mathrm{~b}$ \\
\hline Recovered nutrient $\left(\mathrm{RN}_{\mathrm{N}}\right)^{\mathrm{v}}(\%)$ & $20 \mathrm{a}^{\mathrm{yx}}$ & $19 \mathrm{a}$ & $20 \mathrm{a}$ & $14 \mathrm{~b}$ \\
\hline Nutrient use efficiency $\left(\mathrm{NUE}_{\mathrm{N}}\right)^{\mathrm{u}}(\%)$ & $12 a b^{y x}$ & $11 \mathrm{bc}$ & $15 \mathrm{a}$ & $9 \mathrm{c}$ \\
\hline
\end{tabular}

${ }^{\mathrm{z}} \mathrm{PBS}=8$ pine bark: 1 sand with $1.8 \mathrm{~kg} \cdot \mathrm{m}^{-3}$ dolomitic limestone and $0.9 \mathrm{~kg} \cdot \mathrm{m}^{-3} \mathrm{Micromax}^{\circledR}(\mathrm{Scotts}$ Marysville, $\mathrm{OH}) ; 20 \mathrm{VC}=20 \%$ vermicompost-amended pine bark (by volume); NPK $=17 \mathrm{~N}-2.4 \mathrm{P}-10 \mathrm{~K}$; $\mathrm{NK}=17 \mathrm{~N}-0 \mathrm{P}-10 \mathrm{~K} ; \mathrm{N}=17 \mathrm{~N}-0 \mathrm{P}-0 \mathrm{~K}$.

${ }^{\mathrm{y}}$ Each mean is based on four observations.

${ }^{\mathrm{x}}$ Means within each variable (row) followed by the same letter are not significantly different as determined by Fisher's protected least significant difference at $P \leq 0.05$.

${ }^{\mathrm{w}} \mathrm{RN}_{\mathrm{N}}(\mathrm{mg})=\mathrm{N}$ in plant + effluent + substrate + fertilizer prills

${ }^{\mathrm{v}} \mathrm{RN}_{\mathrm{N}}(\%)=(\mathrm{N}$ in plant + effluent + substrate + fertilizer prills $) \div \mathrm{N}$ inputs $* 100$

${ }^{u} \mathrm{NUE}_{\mathrm{N}}=$ \{plant absorbed nutrient $(\mathrm{mg}) \div$ [applied nutrient $(\mathrm{mg})-$ nutrient remaining in CRF prill nutrient remaining in substrate] $\} * 100$.

Table 5. Phosphorus partition of Hibiscus moscheutos 'Luna Blush' grown with different nutrient inputs at $56 \mathrm{~d}$ after potting.

\begin{tabular}{|c|c|c|c|c|}
\hline Phosphorus partition & $20 \mathrm{VC}+\mathrm{NPK}^{\mathrm{z}}$ & $20 \mathrm{VC}+\mathrm{NK}^{\mathrm{z}}$ & $20 \mathrm{VC}+\mathrm{N}^{\mathrm{z}}$ & $\mathrm{PBS}+\mathrm{NPK}^{\mathrm{z}}$ \\
\hline \multicolumn{5}{|l|}{ Inputs } \\
\hline Fertilizer (mg) & $706^{\mathrm{yx}}$ & 0 & 0 & 706 \\
\hline Vermicompost (mg) & $1,721^{\mathrm{yx}}$ & 172 & 1,721 & 0 \\
\hline \multicolumn{5}{|l|}{ Outputs } \\
\hline Effluent (mg) & $430 \mathrm{a}^{\mathrm{yx}}$ & $395 \mathrm{a}$ & $421 \mathrm{a}$ & $7 \mathrm{~b}$ \\
\hline Hibiscus (mg) & $184 \mathrm{a}^{\mathrm{yx}}$ & $182 \mathrm{a}$ & $190 \mathrm{a}$ & $43 \mathrm{~b}$ \\
\hline \multicolumn{5}{|l|}{ Remaining in system } \\
\hline Substrate (mg) & $83.0 \mathrm{a}^{\mathrm{yx}}$ & $96.7 \mathrm{a}$ & $104.5 \mathrm{a}$ & $4.2 \mathrm{~b}$ \\
\hline Fertilizer prills (mg) & $58.8 \mathrm{a}^{\mathrm{yx}}$ & $0 \mathrm{~b}$ & $0.1 \mathrm{~b}$ & $55.3 \mathrm{a}$ \\
\hline Recovered nutrient $\left(\mathrm{RN}_{\mathrm{P}}\right)^{\mathrm{w}}(\mathrm{mg})$ & $756 \mathrm{a}^{\mathrm{yx}}$ & $674 \mathrm{~b}$ & $716 \mathrm{ab}$ & $110 \mathrm{c}$ \\
\hline Recovered nutrient $\left(\mathrm{RN}_{\mathrm{P}}\right)^{\mathrm{v}}(\%)$ & $31 b^{y x}$ & $39 \mathrm{a}$ & $42 \mathrm{a}$ & $16 \mathrm{c}$ \\
\hline Nutrient use efficiency $\left(\mathrm{NUE}_{\mathrm{P}}\right)^{\mathrm{u}}(\%)$ & $8 b^{\mathrm{yx}}$ & $11 \mathrm{a}$ & $12 \mathrm{a}$ & $7 \mathrm{c}$ \\
\hline
\end{tabular}

${ }^{\mathrm{z} P B S}=8$ pine bark: 1 sand with $1.8 \mathrm{~kg} \cdot \mathrm{m}^{-3}$ dolomitic limestone and $0.9 \mathrm{~kg} \cdot \mathrm{m}^{-3}$ Micromax $^{\circledR}$ (Scotts, Marysville, $\mathrm{OH}) ; 20 \mathrm{VC}=20 \%$ vermicompost-amended pine bark (by vol.); $\mathrm{NPK}=17 \mathrm{~N}-2.4 \mathrm{P}-10 \mathrm{~K} ; \mathrm{NK}=$ $17 \mathrm{~N}-0 \mathrm{P}-10 \mathrm{~K} ; \mathrm{N}=17 \mathrm{~N}-0 \mathrm{P}-0 \mathrm{~K}$.

${ }^{\mathrm{y}}$ Each mean is based on four observations.

${ }^{\mathrm{x}}$ Means within each variable (row) followed by the same letter are not significantly different as determined by Fisher's protected least significant difference at $P \leq 0.05$.

${ }^{\mathrm{w}} \mathrm{RN}_{\mathrm{P}}(\mathrm{mg})=\mathrm{N}$ in plant + effluent + substrate + fertilizer prills.

${ }^{\mathrm{v}} \mathrm{RN}_{\mathrm{P}}(\%)=(\mathrm{N}$ in plant + effluent + substrate + fertilizer prills $) \div \mathrm{N}$ inputs $* 100$.

${ }^{\mathrm{u}} \mathrm{NUE}_{\mathrm{P}}=\{$ plant absorbed nutrient $(\mathrm{mg}) \div$ [applied nutrient $(\mathrm{mg})-$ nutrient remaining in CRF prill nutrient remaining in substrate] $\} * 100$. content average of the VC treatments $(1051$ $\mathrm{mg}$ ) was $352 \mathrm{mg}$ greater than PBS + NPK (699 mg), which is similar to the estimated $\mathrm{N}$ input provided by VC (305 mg). This suggests the estimated available $\mathrm{N}$ provided by $\mathrm{VC}$ was on target. The recovered $\mathrm{N}$ as a percent of total $\mathrm{N}$ inputs $\left(\mathrm{RN}_{\mathrm{N}} \%\right)$ and $\mathrm{N}$ use efficiency $\left(\mathrm{NUE}_{\mathrm{N}}\right)$ of all $20 \mathrm{VC}$ treatments was greater than PBS + NPK (Table 4).

The contents of $P$ recovered $\left(R N_{P}\right)$ for all 20VC treatments were greater than PBS + NPK (Table 5). The $\mathrm{RN}_{\mathrm{P}}$ content ranged from 560 to $650 \mathrm{mg}$ greater than that recovered from PBS + NPK (100 mg). This difference is $33 \%$ to $38 \%$ of that estimated $\mathrm{P}$ from VC. This may indicate that the available $\mathrm{P}$ content provided by VC was overestimated. Predicting the availability of $\mathrm{P}$ is difficult, because $\mathrm{P}$ release from compost is governed by complex interactions of chemical and physical conditions. An overestimate of $\mathrm{P}$ is conservative with respect to determining efficiency measures. Regardless, this source of VC provided sufficient $\mathrm{P}$ such that additional $\mathrm{P}$ inputs from fertilizer or other sources are not necessary. Both the percent of $\mathrm{P}$ input that was recovered $\left(\mathrm{RN}_{\mathrm{P}} \%\right)$ and the phosphorus use efficiency $\left(\mathrm{NUE}_{\mathrm{P}}\right)$ would be underestimated if the $\mathrm{P}$ input is overestimated. The $\mathrm{RN}_{\mathrm{P}} \%$ and $\mathrm{NUE}_{\mathrm{P}}$ of the $20 \mathrm{VC}$ treatments were greater than the PBS + NPK (Table 5).

For $20 \mathrm{VC}+\mathrm{NPK}, 20 \mathrm{VC}+\mathrm{NK}, 20 \mathrm{VC}+$ $\mathrm{N}$, and $\mathrm{PBS}+\mathrm{NPK}$, the $\mathrm{NUE}_{\mathrm{N}}$ was $12 \%$, $11 \%, 15 \%$, and $9 \%$ and $\mathrm{NUE}_{\mathrm{P}}$ was $8 \%, 11 \%$, $12 \%$, and $7 \%$, respectively (Tables 4 and 5 ). These nutrient use efficiency values are at the lower end of the ranges reported by others (Owen et al., 2008; Ristvey et al., 2007; Stoven et al., 2006). For azalea (Rhododendron var. L. 'Karen') grown in 2002 fertilizer treatments in which decreased growth was not detected, the $\mathrm{NUE}_{\mathrm{N}}$ and $\mathrm{NUE}_{\mathrm{P}}$ ranged from $12 \%$ to $28 \%$ and $14 \%$ to $49 \%$, respectively (Ristvey et al., 2007). These higher nutrient use efficiencies were associated with lower respective $\mathrm{N}$ and $\mathrm{P}$ fertilization rates. Owen et al. (2008) also reported an increased $\mathrm{NUE}_{\mathrm{P}}$ from $21 \%$ to $34 \%$ when cotoneaster (Cotoneaster dammeri Schnied. 'Skogholm') grown in a pine bark sand substrate received $\mathrm{P}$ at a full rate and half rate, respectively. Specific crop nutrient requirements will also influence nutrient use efficiencies. Stoven et al. (2006) reported $\mathrm{NUE}_{\mathrm{N}}$ of $6 \%, 14 \%$, $36 \%$, and $55 \%$ for Quercus rubra L. (red oak), Malus (Mill.) 'Prairifire' (Prairifire crabapple), Cercis canadensis L. (Eastern redbud), and Acer ×freemai 'Jeffersred' (Autumn Blaze ${ }^{\circledR}$ maple), respectively, when grown outdoors and fertilized with CRF. Reduction of LF is another approach to improve nutrient use efficiency (Fare et al., 1994; McGinnis, 2007; Owen et al., 2008; Tyler et al., 1996). Leaching fraction reduction results in decreased nutrient effluent volume and content. Consequently, the nutrients not lost with the effluent remain in the container and can be absorbed by the plant, resulting in greater nutrient use efficiency.

In conclusion, nutrient uptake of $\mathrm{P}, \mathrm{Ca}$, $\mathrm{Mg}, \mathrm{S}, \mathrm{Fe}, \mathrm{Mn}, \mathrm{Zn}, \mathrm{Cu}$, and $\mathrm{B}$ was equivalent 
or greater by hibiscus-grown pine bark amended with this source of vermicomposted pig manure ( $20 \%$ by vol.) compared with plants grown with conventional nutrient conventional nursery crop nutrient inputs (dolomitic limestone, sulfated micronutrients, and $\mathrm{P}$ in the CRF). This source of VC did not supply equivalent $\mathrm{K}$ as conventional CRFs. Although the lower K uptake did not reduce plant growth, the addition of fertilizer $\mathrm{K}$ is recommended to fertilizer. $\mathrm{K}$ should be provided to this source of $\mathrm{VC}$ at a $20 \%$ amendment rate. Furthermore, hibiscus grown in all $20 \%$ VC treatments produced $40 \%$ greater plant dry weight and 93\% more flowers compared with hibiscus grown in the industry standard treatment, yet all treatments used equivalent volumes of water. The effluent volumes for all treatments were also equivalent; however, the effluent content of IN-N and DRP was much greater for VC treatments. The drawback of greater effluent nutrient content when using a $\mathrm{VC}$ amended substrate could be offset by implementing best management practices such as the reduction of LF and/or containment or capture of the effluent.

\section{Literature Cited}

Albanell, E., J. Plaixats, and T. Cabrero. 1988. Chemical changes during vermicomposting (Eisenia foetida) of sheep manure mixed with cotton industrial wastes. Biol. Fertil. Soils 6:266-269.

Arancon, N.Q., C.A. Edwards, A. Atiyeh, and J.D. Metzger. 2004. Effects of vermicomposts produced from food waste on the growth and yields of greenhouse peppers. Bioresour. Technol. 93:139-144.

Arancon, N.Q., C.A. Edwards, A. Babenko, J. Cannon, P. Galvis, and J.D. Metzger. 2008. Influences of vermicomposts, produced by earthworms and microorganisms from cattle manure, food waste and paper waste, on the germination, growth and flowering of petunias in the greenhouse. Appl. Soil Ecol. 39:91-99.

Atiyeh, R.M., N.Q. Arnacon, C.A. Edwards, and J.D. Metzger. 2002. The influence of earthwormprocessed pig manure on the growth and productivity of marigolds. Bioresour. Technol. 81:103-108.

Atiyeh, R.M., J. Dominguez, S. Subler, and C.A. Edwards. 2000. Changes in biochemical properties of cow manure during processing by earthworms (Eisenia Andrei) and the effects on seedling growth. Pedobiologia (Jena) 44: 709-724.

Atiyeh, R.M., C.A. Edwards, S. Subler, and J.D. Metzger. 2001. Pig manure vermicompost as a component of a horticultural bedding plant medium: Effects on physiochemical properties and plant growth. Bioresour. Technol. 78:11-20.
Bachman, G.R. and W.E. Davis. 2000. Growth of Magnolia virginiana liners in vermicompostamended media. Proc. SNA Res. Conf., FortyFifth Annu. Rpt. p. 65-76.

Bachman, G.R. and J.D. Metzger. 2007. Physical and chemical characteristics of a commercial potting substrate amended with vermicompost produced from two different manure sources. HortTechnology 17:336-340.

Bachman, G.R. and J.D. Metzger. 2008. Growth of beddings plants in commercial potting substrate amended with vermicompost. Bioresour. Technol. 99:3155-3161.

Baldwin, K.R. and J.T. Greenfield. 2006. Composting on organic farms. NC Coop. Ext. Serv. AG-659W01.14 Jan. 2009. <http://www.cefs. ncsu.edu/PDFs/Organic\%20Production \%20$\% 20$ Composting.pdf $>$.

Campbell, C.R. 1992. Determination of total nitrogen in plant tissue by combustion, p. 21-23. In: Plank, C.O. (ed.). Plant analysis reference procedures for the southern region of the United States. GA Coop. Ext. Serv. Southern Coop. Ser. Bul. 368, Athens, GA.

Campbell, C.R. and C.O. Plank. 1992. Sample preparation, p. 8-9. In: Plank, C.O. (ed.). Plant analysis reference procedures for the southern region of the United States. GA Coop. Ext. Serv. Southern Coop. Ser. Bul. 368, Athens, GA.

Donohue, S.J. and D.W. Aho. 1992. Determination of $\mathrm{P}, \mathrm{K}, \mathrm{Ca}, \mathrm{Mg}, \mathrm{Mn}, \mathrm{Fe}, \mathrm{Al}, \mathrm{B}, \mathrm{Cu}$, and $\mathrm{Zn}$ in plant tissue by inductively coupled plasma (ICP) emission spectroscopy, p. 37-40. In: Plank, C.O. (ed.). Plant analysis reference procedures for the southern region of the United States. GA Coop. Ext. Serv. Southern Coop. Ser. Bul. 368, Athens, GA.

Edwards, C.A. 1995. Historical overview of vermicomposting. Biocycle 36:50-54.

Epstein, E. and A.J. Bloom. 2005. Mineral nutrition of plants: Principles and perspectives. 2nd ed. Sinauer Assoc., Sunderland, MA.

Fare, D.C., C.H. Gilliam, and G.J. Keever. 1994 Cyclic irrigation reduces container leachate nitrate-nitrogen concentration. HortScience 29: 1514-1517.

Handreck, K. 1986. Vermicomposts as components of potting media. Biocycle 27:58-62.

Hartenstein, R. and F. Hartenstein. 1981. Physiochemical changes in activated sludge by earthworm Eisenia foetida. J. Environ. Qual. 10:377-382

Hidalgo, P.R. and R.L. Harkess. 2002. Earthworm castings as a substrate amendment for chrysanthemum production. HortScience 37:1035-1039.

Hidalgo, P.R., F.B. Matta, and R.L. Harkess. 2006. Physical and chemical properties of substrates containing earthworm castings and effects on marigold growth. HortScience 41: 1474-1476.

McGinnis, M., T. Bilderback, and S. Warren. 2005. Vermicompost: Improving water use efficiency in nursery crop production. Proc. Southern Nurs. Assoc. Res. Conf. 50:73-77.

McGinnis, M.S. 2007. Sustainable use of vermicomposted hog waste: The use of worm cast- ings as nursery growing substrates amendment to increase water and nutrient efficiency in containerized nursery plant production. $\mathrm{PhD}$ Diss, NC State Univ., Raleigh, NC.

McGinnis, M.S., M.G. Wagger, S.L. Warren, and T. Bilderback. 2010. Nutrient contribution and release kinetics of vermicompost amended pine bark. Compost Sci. Util. In press.

Mehlich, A., S.S. Bowling, and A.L. Hatfield. 1976. Buffer $\mathrm{pH}$ acidity in relation to nature of soil acidity and expression of lime requirement. Commun. Soil Sci. Plant Anal. 7:253263.

Mill, H.A. and J.B. Jones, Jr. 1991. Plant analysis handbook. II. A practical sampling, preparation, analysis, and interpretation guide. MicroMacro Publishing, Inc., Athens, GA.

Nair, V.D., D.A. Graetz, and D.O. Dooley. 2003. Phosphorus release characteristics of manure and manure-impacted soils. Food, Agr., \& Envr. 1:217-223.

Owen, J.S., Jr., S.L. Warren, T.E. Bilderback, and J.P. Albano. 2008. Phosphorus rate, leaching fraction, and substrate influence on influent quantity, effluent nutrient content, and response of a containerized wood ornamental crop. HortScience 43:906-912.

Pilon, P. 2006. Hibiscus moscheutos Luna series. Greenhouse Production News. 4 Mar. 2009 $<$ http://www.gpnmag.com/articles/020610.pdf>.

Ristvey, A.G., J.D. Lea-Cox, and D.S. Ross. 2007. Nitrogen and phosphorus uptake efficiency and partitioning of container-grown azalea during spring growth. J. Amer. Soc. Hort. Sci. 132: 563-571.

Stoven, A.A., H.M. Mathers, and D.K. Struve. 2006. Fertilizer application methods affects growth, nutrient, and water use efficiency of container-grown shade tree whips. HortScience 41:1206-1212.

Sylvia, D.M., J.J. Fuhrmann, P.G. Hartel, and D.A. Zuberer. 2005. Principles and applications of soil microbiology. 2nd Ed. Prentice Hall, Upper Saddle River, NJ.

Thompson, W.H. (ed.). 2003. Phosphorus, p. 04.03-1. In: Test methods for the examination of composting and compost. Prepared for the US. Composting Council Research and Education Foundation and the U.S. Dept of Agr.

Tomati, U. and E. Galli. 1995. Earthworms, soil fertility, and plant productivity. Acta Zool. Fenn. 196:11-14.

Tyler, H.H., S.L. Warren, and T.E. Bilderback. 1996. Reduced leaching fractions improve irrigation use efficiency and nutrient efficacy. J. Environ. Hort. 14:199-204.

Wyn-Jones, R., C. Brady, and J. Spiers. 1979. Ionic and osmotic relations in plant cells, p. 63-103. In: Laydman, D. (ed.). Recent advances in the biochemistry of cereals. Academic Press, London, UK.

Yeager, T.H., C.H. Gilliam, T.E. Bilderback, D.C. Fare, A.X. Niemiera, K.M. Tilt, and S.W. Warren. 2007. Best management practices: Guide for producing container-grown plants. Southern Nursery Assoc., Marietta, GA. 